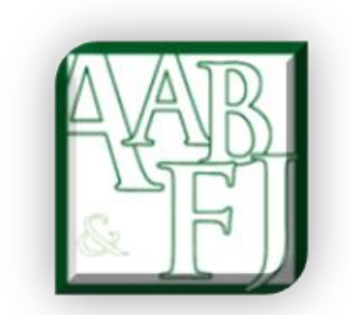

\title{
Does Gender Diversity on Board Promote Corporate Social Responsibility? An Empirical Analysis of Sustainable Development Goal
}

\author{
Amit Kumar Singh ${ }^{1}$, Hima Bindu Kota ${ }^{2}$, Varda Sardana ${ }^{3}$ and Shubham Singhania ${ }^{4}$
}

Abstract: Recent regulatory changes in India require the firms to improve the appointment of female directors on corporate boards, and it is believed that such a regulation would prove to be a boon in terms of strategic decision making. The Board Capital Theory advocates that the appointment of women directors on board shall enhance various dimensions of the board capital breadth and help in better decision making. With growing consciousness for sustainable practices throughout the globe, it is pertinent to see whether the gender diverse boards can promote corporate social responsibility and create a business case for their upsurge, as it would give room for policy implications. This study investigates the impact of gender diverse boards on promoting corporate social responsibility, using multivariate regression with a sample of NIFTY 50 Index for the period 2014-2019. The study found insignificant positive relation among gender-diverse boards and sustainability. To check for the robustness of the study, we have used two diversity indices, Blau \& Shannon index, to supplement our results.

Keywords: Gender Diversity, Sustainability, Corporate Governance, NIFTY 50 Companies.

JEL Classification: G30, G38, J16, M14

\footnotetext{
${ }^{1}$ University of Delhi, India.

${ }^{2}$ Amity University, India

${ }^{3}$ University of Delhi, India.

${ }^{4}$ Technological University, India.
} 


\section{INTRODUCTION}

Corporate Social Responsibility (CSR) reporting refers to the act of communicating the effect of various economic actions undertaken by the firms on the social and environmental domain. In simple words, we can infer that any impact caused by the firms towards the society and environment has to be informed to all the stakeholders (Jamali and Neville, 2011; Jamali, El Dirani and Harwood, 2015). The Iron Law of Responsibility states that the corporate entities shall make voluntary efforts to make valuable contribution towards the society, since they have been recklessly using society's resources. In this context, it becomes imperative for the firms to make contributions towards the society. To promote such measures by the firms, the Companies Act 2013 has made it compulsory for some companies to contribute $2 \%$ of the average net profits towards CSR related activities.

Since all major decisions regarding the management of the firms are undertaken by the board of directors, they are imperative for promoting CSR related issues (Muttakin, Khan and Mihret, 2018). Owing to various debacles taking places across the globe, the board composition has undergone a sea change, and the research studies on corporate governance has seen an upsurge. With growing consciousness throughout the world, the major changes in composition have been in terms of making the board diverse, with a specific emphasize on the inclusion of females- through mandatory or voluntary provisions. Amongst the various boards related components, gender diversity has received growing interest from researchers.

The Sustainable Development Goals of the United Nations, specifically SDG-5 has also emphasized the growing role of gender equality on various dimensions be it business, academic, political \& social arena. Women have been acting as change agents as their presence in the process of making decisions tends to influence the board strategy (Nielsen and Huse, 2010b) and their presence have made things more independent \& objective (Fondas, 2000). Some authors also tend to believe that they bring upon a different perspective, different outlook, various alternatives in terms of decision making and leads to problem solving(Rao and Tilt, 2016).In the light of the benefits it is believed that gender equality on board would prove to be highly beneficial not only as a matter of social upliftment of women but also in economic sense.

Countries like Norway, Sweden and Denmark have mandated the appointment of female directors on the board of companies. On similar lines, in India, the Companies (Amendment) Act, 2013 requires the board of certain category of companies to have at least one-woman director. According to Moreno-Gómez, Lafuente and Vaillant (2018), social perspective of feminist groups means that females tends to choose strategies that are different from that of males and hence, gender diversity plays a big role in decision making. Board gender diversity may present a lot of opportunities in terms of having a diverse opinion, and it might affect the CSR related disclosures and other essential issues, since it is unnatural to have a homogenous set of stakeholders for any business. Taking these studies as the basis, we can postulate that the working style of female directors is different from that of their male counterparts (AlonsoAlmeida, Perramon and Bagur-Femenias, 2017). Therefore, having gender diverse boards would certainly help in better CSR related decisions.

Previous research studies in the field of gender diversity have looked it from the perspective of financial performance (Campbell and Mínguez-Vera, 2008; Abdelzaher and Abdelzaher, 2019; Herrera-Cano and Gonzalez-Perez, 2019). But there has not been much research contributions in terms of investigating whether gender diverse boards affect corporate social responsibility. 
For the Indian scenario, Sanan (2016) in her study looked at the impact of presence of both males and females on boards on social performance to capture the socially responsible behaviour of the firms, by creating a CSR index. However, it did not give significant results. Motivated by the fact that not much studies have been done in this respect, it is pertinent for the interest of various stakeholders to know whether the presence of women directors on corporate boards have any significant business case or they are a mere form of tokenism.

Therefore, this study focusses on evaluating the impact of gender diversity on board in promoting CSR. Section 2 outlines the conceptual model developed for the study. Section 3 highlights the extensive literature review on gender diversity \& CSR. Section 4 mentions about the research gap based on the extensive literature. Section 5 and 6 covers the objective and hypothesis. Section 7 looks after the research methodology. Section 8 and 9 elaborates on the results and conclusions, and lastly, section 10 summarises the policy implications, future scope, and limitations of the study.

\section{CONCEPTUAL MODEL FOR THE STUDY}

The systematic review of several studies based on theories such as agency, stakeholder, resource dependence, and legitimacy theory postulates how gender diversity on board can affect the decisions with respect to corporate social responsibility and promote sustainable development. In a large number of studies, the results have suggested that the presence of women directors on board have impacted the CSR positively (Bear, Rahman and Post, 2010). There are evidences which also report that the presence of gender diversity on board impacts several dimensions of CSR, such as the level of charity by the firms (Wang and Coffey, 1992) as well as the environment based CSR (Post, Rahman and Rubow, 2011). Thus, in this study, we have used CSR expenditure as a proxy variable to measure the impact caused by gender diversity on board in promoting corporate social responsibility.

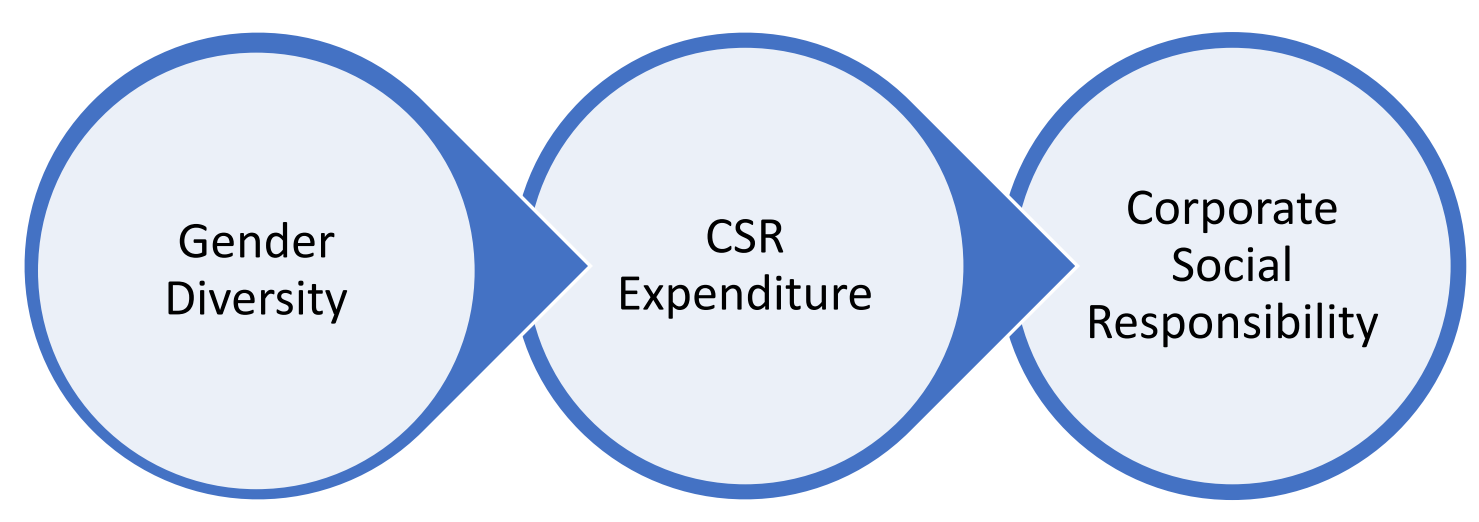

Figure.1 Conceptual Model on Gender Diversity \& Corporate Social Responsibility

\section{REVIEW OF LITERATURE}

\subsection{Role of Gender Diversity on Board}

Diversity, in terms of gender, on corporate boards in a firm, can influence decision making in 
various ways. As per Nielsen and Huse (2010a), board of directors usually work in groups or teams, and hence variation in a group can certainly lead to rise in knowledge, abilities as well as information. Increased innovation, novice ideas, greater market penetration capability, efficiency in problem solving \& corporate leadership, efficient global relationships; all of these benefits can accrue to a firm on account of gender diversity in its leadership (Robinson and Dechant, 1997). The existence of women on board may help in improving the image of the firm, which would ultimately have a positive impact on customer behaviour (Smith, Smith and Verner, 2006). Women are found to have provided uncommon perspectives, and bring in unique experiences as well as working to the firm, while making decisions (Daily and Dalton, 2003). Female directors have an inverse relation with accounting manipulations (Abdullah, Ismail and Nachum, 2016) as well, and they are more inclined towards asking questions, so that the decisions are not finalised without adequate discussions (KONRAD, KRAMER and ERKUT, 2008). Stakeholder and Gender Socialisation Theory advocates that heterogeneity in the top management will certainly lead to the better decision-making quality (Chams and García-Blandón, 2019). Rahman, Ibrahim and Che Ahmad (2017) also found that heterogeneity at the top-level management plays a role in reducing the level of agency conflicts within the company.

On the other hand, a homogenous board, with directors having similarity on thought, shall certainly lead to congruence in perspective and conformity in decision making (Van Knippenberg, De Dreu and Homan, 2004). It has also been observed that heterogenous boards achieve better during uncertainty, whereas homogenous boards achieve better in stable conditions (Nielsen and Huse, 2010a). Any negative effects of board gender diversity, such conflicts, may get moderated overtime when directors become aware about each other (Harjoto, Laksmana and Lee, 2015). When it comes to sustainability, Nadeem, Zaman and Saleem (2017) suggest that women's representation on board would improve decision making in the context of sustainability as the diversity present shall together bring diverse range of expertise and knowledge. Female representation on board brings in different work styles on board and leads to better adaptation to the environment (Mínguez-Vera and López-Martínez, 2010).

\subsection{Corporate Social Responsibility of Companies and their Disclosure}

As per Liao et al. (2018), corporate sustainability disclosures are meant to consider the contribution of companies or entities in broadly 3 parameters: social, economic sustainability \& environmental aspect. In India, Clause 55 of Listing Agreement requires firms to have Business Responsibility Reports (BRR) based on the Framework of National Voluntary Guidelines (NVG). However, there is limited literature and studies undertaken as to disclosure of CSR requirements by corporates.

While undertaking disclosures, legitimacy theory, that is congruency between the society's expectations and company's value systems plays an important role. The quality of such disclosures would also be subjective and context dependent (Beattie, McInnes and Fearnley, 2004).According to a study by Prasad, Mishra and Kalro (2017), the extent of disclosures have increased from 2011-12 to 2014-15, but they are not significant. Moreover, the quality of disclosures has also improved, but like quantity, this is also not significant.

\subsection{Women and Sustainability Practices}

Multiple studies have pointed towards the outlook of women in general, as well as women directors towards corporate sustainability and social responsibility. Males and females differ in their values especially when it comes to the corporate social performance (Post, Rahman and Rubow, 2011). It has also been advocated that firms with women representation on the 
boards are found to violate less environmental concerns (Donaldson and Preston, 1995). According to Stakeholder Theory, women possess some communal qualities such as helpfulness, kindness, sympathy, interpersonal sensitivity, etc. which may facilitate their say, based on stakeholders claims and expectations (Eagly, Johannesen-Schmidt and Van Engen, 2003).

Women's communal qualities also help them in taking decisions, considering their social responsibility (Tourigny, Han and Baba, 2017). This is reiterated by the Social Role Theory as well, as per which women are shown to portray communal qualities (such as generosity, social orientation, concern) while men showcase agentic qualities (such ambitious, self-directed) (Doherty and Eagly, 1989; Eagly and Wood, 1991). Men are prone to pay emphasise on their tasks, whereas women are social butterflies and are oriented towards others (Major and Forcey, 1985; Eagly and Karau, 1991) While men are inclined towards following and promoting fairness and obligations, women are more likely to have long term relationships and caring for others' needs (Gilligan, 1977). Hence, presence of women directors on board, even if one, shall create a difference in the sustainability practises of the firm (Zaichkowsky, 2014).

The reason for this is that women directors are relatively less power-hungry, and hence they show strong traits like kindness \& compassion. This enables them look up to the protection of the nature and other people (Adams and Funk, 2012). Women are considered to be more ethical, have better communication skills, and better participation which enables them to have better concern for society and environment, and hence better CSR reporting (Kesner, 1988).

Agency Theory postulates that information failure as well as agency conflicts on the board shall reduce due to the presence of women directors, thereby improving the quality of corporate social responsibility (Reguera-Alvarado, de Fuentes and Laffarga, 2017). The Resource Dependency Theory advocates that the presence of female directors shall turn out to be fruitful for the CSR disclosures, since they would, through their connections, maintain legitimacy between the society and stakeholders (Lückerath-Rovers, 2013). Additionally, the Gender Socialisation Theory believes that the leadership styles adopted by female directors is more ethical and socially inclined than that of male directors, and hence they are more stakeholderoriented, which enhances the quality of CSR reporting (Landry, Bernardi and Bosco, 2016).

According to Zahid et al. (2020), diversity on board leads to a significant impact on the corporate sustainability disclosures (CSD), and CSD was found to be better in firms where the women were present in the top management. In another study Al Fadli et al., (2019) found that the presence of female directors on board of Jordanian public listed companies enhanced CSRT reporting practises. Similarly, as per Pucheta-Martínez, Bel-Oms and Olcina-Sempere (2019), increase in the ratio of women directors (independent $\&$ institutional directors) on boards, up to a certain threshold limit would lead to better CSR disclosure. However, increasing the proportion beyond the threshold limit may lead to fall or decrease in the CSR disclosures. One exception to this is the study conducted by Sanan (2016), which did not find any significant impact of gender based diversity on firms financial and social performance.

\section{RESEARCH GAP}

The past literature makes it clear that gender diversity \& financial performance is a wellresearched area, both globally as well as in the Indian context. Much of the earlier literature has focussed on finding the nexus between corporate governance and financial performance (Rahman, Ibrahim and Ahmad, 2017). However, there is not much literature which taps the relation between gender diversity and sustainability or corporate social responsibility. There is 
a dearth of research, specifically in the Indian context. Hence, as per our knowledge, this study is amongst the first ones that tries to ascertain the effect of gender diversity and presence of women on company boards, on the sustainability and socially responsible behavior of companies.

Due to differences in institutional and cultural environment of various developing \& developed countries various attributes of corporate governance, in the form of board diversity and the like, may vary. Byron and Post (2016) have documented that institutional level factors will certainly affect the outcomes of the studies in different countries. In India, the economy has been rooted in terms of socio-cultural barriers for women, whereas in the West side, the women's life in terms of the working, lifestyle and education is not entirely based on the social and cultural norms. This makes it even more essential to undertake such a study in a developing country, like India.

\section{OBJECTIVES}

The major aim of the study is to determine the impact of gender diversity on large firms' board, on promoting corporate social responsibility.

\section{HYPOTHESIS}

$\mathrm{H}_{\mathrm{o}}$ : The proportion of women on board has no effect on the CSR expenditure of firm.

Ha1: The proportion of women on board affects CSR expenditure of firm.

$\mathrm{H}_{\mathrm{o} 2}$ : Leverage in a firm has no effect on the CSR expenditure of firm.

$\mathrm{H}_{\mathrm{a} 2}$ : Leverage in a firm affects the CSR expenditure of firm.

Ho3: The size of a firm has no effect on the CSR expenditure of firm.

Ha3: The size of a firm affects the CSR expenditure of firm.

Ho4: Return on assets of a firm has no effect on the CSR expenditure of firm.

Ha4: Return on assets of a firm affects the CSR expenditure of firm.

Ho5: Age of a firm has no effect on the CSR expenditure of firm.

Has: Age of a firm affects the CSR expenditure of firm.

Ho6: Board size of a firm has no effect on the CSR expenditure of firm.

Ha6: Board size of a firm affects the CSR expenditure of firm.

\section{RESEARCH METHODOLOGY}

\subsection{Data Collection Sources}

We have used five sources for the purpose of data collection. These are as follows:

1. Prime Database Group: The database was used to collect complete data on directors of the corporates and composition of boards for various Indian firms listed on National Stock Exchange (NSE).

2. Indianboards.com: This was used as a supplementary source to collect data regarding board of directors of firms in our sample.

3. CMIE PROWESS: Prowess was used to collect indicators and measures of financial performance and CSR performance of firms on NSE.

4. Capitaline Database: This database was tapped for sourcing annual reports of companies.

5. Corporate Governance \& CSR Reports of the firms: These reports were used to collect data regarding CSR expenditure of firms in our sample.

\subsection{Sample}

We started with the NIFTY 50 companies for the analysis, which have been taken as the large firms. Out of these, banking companies were eliminated as these companies follow the Banking 
Regulations Act, 1949, and hence have different regulations regarding CSR. After removing the companies with missing data, a total of 42 firms were finally included for the study. A five-year sample period, from 2014 to 2019 was considered to measure the impact of gender diversity on corporate sustainability of firms, thereby leading to a total of 210 data points. The period beginning from 2014 has been considered because the mandatory compliance with CSR requirements became a part of the Companies Act in the year 2013.

\subsection{Variables}

\section{Dependent Variable}

Corporate Social Responsibility has become the buzzword in the current scenario, and efforts are being made in all respect by corporate houses to make valuable contribution to the society at large. Therefore, to measure the efforts undertaken by these firms, we have used CSR expenditure incurred by the firms as the dependent variable.

\section{CSR Expenditure}

Corporate Social Responsibility is measured as the expenditure incurred by a company on social as well as sustainability related issues. This variable shall act as a proxy for Corporate Social Responsibility initiatives taken by the firm. Though other studies have used the CSR ratings provided by some credible database sources (Francoeur et al., 2019) or have created CSR reporting index (Ahmad, Rashid and Gow, 2017) using content analysis of the annual reports to measure the CSR based aspects, in case of India such ratings are not available as of now, hence CSR expenditure as a variable has been widely used in several studies (Verma and Vijaya Kumar, 2014; Prasad, Mishra and Bapat, 2019).

\section{Independent Variables}

Table 1: Summary of Independent Variables

\begin{tabular}{|l|l|l|}
\hline $\begin{array}{l}\text { Independent } \\
\text { Variable }\end{array}$ & Measure & Literature \\
\hline P-Women & $\begin{array}{l}\text { Percentage of women directors on board with } \\
\text { respect to the total directors. }\end{array}$ & $\begin{array}{l}\text { (Campbell and Mínguez-Vera, } \\
2008 ; \quad \text { Giraldez-Puig and } \\
\text { Berenguer, 2018; Haldar et al., } \\
2018 ; \text { Chancharat and Chancharat, } \\
2019 ; \text { Hashim, Ahmed and Huey, } \\
\text { 2019) }\end{array}$ \\
\hline Blau Index & A measure of gender diversity & $\begin{array}{l}\text { (Campbell and Mínguez-Vera, } \\
\text { 2008; Issa and Fang, 2019; Singh, } \\
\text { Singhania and Sardana, 2019) }\end{array}$ \\
\hline Shannon Index & A measure of gender diversity & $\begin{array}{l}\text { (Campbell and Mínguez-Vera, } \\
\text { 2008; Issa and Fang, 2019) }\end{array}$ \\
\hline Leverage & $\begin{array}{l}\text { Calculated as the ratio of total long-term debt } \\
\text { to the total assets. }\end{array}$ & $\begin{array}{l}\text { Sanan, 2016; Karim, Manab and } \\
\text { Ismail, 2019; Pucheta-Martínez } \\
\text { and Gallego-Álvarez, 2019) }\end{array}$ \\
\hline Firm Size & $\begin{array}{l}\text { Measured in terms of the natural log of the total } \\
\text { assets }\end{array}$ & $\begin{array}{l}\text { Karim, Manab and Ismail, 2019; } \\
\text { Pucheta-Martínez, Bel-Oms and } \\
\text { Olcina-Sempere, 2019) }\end{array}$ \\
\hline $\begin{array}{l}\text { Profitability } \\
\text { Return } \\
\text { Asset) }\end{array}$ & $\begin{array}{l}\text { Percentage of profits earned against the total } \\
\text { assets employed by a firm }\end{array}$ & $\begin{array}{l}\text { (Pucheta-Martínez, Bel-Oms and } \\
\text { Olcina-Sempere, 2019; Valls } \\
\text { Martínez, Cruz Rambaud and Parra } \\
\text { Oller, 2019) }\end{array}$ \\
\hline
\end{tabular}




\begin{tabular}{|l|l|l|}
\hline Age & $\begin{array}{l}\text { Measured as the number of years for which the } \\
\text { firm has lived from the date of its } \\
\text { incorporation. }\end{array}$ & $\begin{array}{l}\text { (Francoeur et al., 2019; Zahid et } \\
\text { al., 2020) }\end{array}$ \\
\hline Board Size & $\begin{array}{l}\text { Number of directors' present in the Board of } \\
\text { the firm. }\end{array}$ & $\begin{array}{l}\text { (Sanan, 2016; Charumathi and } \\
\text { Rahman, 2019; Issa and Fang, } \\
\text { 2019; Pucheta-Martínez, Bel-Oms } \\
\text { and Olcina-Sempere, 2019) }\end{array}$ \\
\hline
\end{tabular}

\section{Proportion of women on board (P-woman)}

$\mathrm{P}$-woman refers to the proportion of female directors on the corporate boards. This variable has been used as a proxy measure of gender diversity on the board of the firms. Literature suggests that existence of women directors on board leads to a positive impact on organisational innovation, diversity in perspectives and hence better decision making (Torchia, Calabrò and Huse, 2011). Board diversity also provides opportunities for strategic alliances and better relationship with other firms and corporate groups (Haldar, Shah and Nageswara Rao, 2015). Hence, various studies have used P-woman to measure for gender diversity on board and its impact on various firm related aspects (Campbell and Mínguez-Vera, 2008; Giraldez-Puig and Berenguer, 2018; Haldar et al., 2018)

\section{BLAU Index}

The Blau index is a well know variable used to measure diversity. It is calculated as:

$$
D=1-\sum_{i=1}^{N} p_{i}^{2}
$$

Where $\mathrm{p}$ denotes the proportion of objects in the categories and

$\mathrm{N}$ denotes the number of categories.

The value of Blau Index varies from 0 to 0.5 (lowest to highest diversity). It has been employed in order to improve the the robustness of the study (Campbell and Mínguez-Vera, 2008; Issa and Fang, 2019; Singh, Singhania and Sardana, 2019).

\section{SHANNON Index}

The Shannon index aims to state the uncertainty in predicting the species identity of any person chosen randomly from a given set of data. It is calculated as:

$$
H^{\prime}=-\sum_{i=1}^{S} p_{i} \ln p_{i}
$$

Where $\mathrm{p}$ denotes the proportion of objects in the categories and

$\mathrm{S}$ denotes the number of categories.

The value of Shannon Index varies from 0 to 0.69 (lowest to highest diversity). Like Blau Index, Shannon Index also enhances the robustness of the study (Campbell and Mínguez-Vera, 2008; Issa and Fang, 2019; Singh, Singhania and Sardana, 2019)

\section{Control Variables}

\section{Leverage}

Leverage of any organisation is calculated as the ratio of debt to assets. In the previous literature. it has been documented that leverage shall negatively affect CSR (Waddock and Graves, 1997; Campbell, 2007) and has been empirically used in several other studies (Sanan, 2016; Issa and Fang, 2019; Karim, Manab and Ismail, 2019; Pucheta-Martínez, Bel-Oms and Olcina-Sempere, 2019).

\section{Firm Size}


Firm size has been measured with respect to the total assets. Based on the extant literature, it has been observed that larger firms are inclined towards behaving in a socially responsible manner (McWilliams and Siegel, 2001; Barnea and Rubin, 2010) and therefore we expect that it is certainly going to affect the corporate social responsibility activities. This variable has been used in multiple past studies as well (Issa and Fang, 2019; Karim, Manab and Ismail, 2019; Pucheta-Martínez, Bel-Oms and Olcina-Sempere, 2019).

\section{Profitability (Return on Assets)}

Return on assets is calculated as the percentage of profits earned against the total assets employed in a firm. This variable influences the financial performance and, thus, is likely to affect the corporate social responsibility measures of the firms (Haniffa and Cooke, 2005). The CSR disclosure of profitable firms is also larger as has been used and advocated in various other studies (Pucheta-Martínez, Bel-Oms and Olcina-Sempere, 2019; Valls Martínez, Cruz Rambaud and Parra Oller, 2019).

\section{Age}

The age of the firm is measured by the number of years the firm has lived from the date of its incorporation. Also, the age of the firm defines the number of years for which the firm has been in existence and has been using societal resources. Based on the Iron Law of Responsibility, age of the firm should have a positive impact on the CSR (Jo and Harjoto, 2011) and has been used in several studies as well to measure social performance \& sustainability issues (Francoeur et al., 2019; Zahid et al., 2020).

\section{Board Size}

Board size refers to the number of directors' present on the board of the firm. Board size is a crucial element in the decision making of the firms. It has been suggested that larger boards tends to disclose more CSR related information (Esa and Ghazali, 2012) and therefore it is likely that the board size shall impact the decisions taken with respect to the corporate social responsibility measures undertaken by the firms, and has been used extensively in literature (Sanan, 2016; Issa and Fang, 2019; Karim, Manab and Ismail, 2019; Pucheta-Martínez, BelOms and Olcina-Sempere, 2019).

\subsection{Research Technique and Model Specification}

The technique employed for the study is the Multivariate Regression Analysis. Ordinary least squares (OLS) method of regression is used for the analysis.

We have employed a balanced panel data as this method allows us to remove any unobservable heterogeneity in the sample. In case where unobservable heterogeneity is present, and it is correlated with our independent variables, we conduct an estimation by fixed effects model. Otherwise, we undertake a random effects model. To check for such kind of correlation, we used the Hausman Test (Hausman and Taylor, 1981), whose results have been displayed in the upcoming sections.

Three models were run using the OLS regression, the specifications of which are as follows:

Model 1-CSR $\boldsymbol{C R}_{i t}=\beta_{0}+\Sigma \beta_{1} P-W O M A N_{i t}+\Sigma \beta_{2} L E V E R_{i t}+\Sigma \beta_{3} F-S I Z E_{i t}+\Sigma \beta_{4} R_{O A} A_{i t}+\Sigma \beta_{5} A G E_{i t}$ $+\Sigma \beta_{6} B-S I Z E_{i t}+\varepsilon_{i t}$

Model 2-CSR $R_{i t}=\beta_{0}+\Sigma \beta_{1} B L A U_{i t}+\Sigma \beta_{2} L E V E R_{i t}+\Sigma \beta_{3} F-S I Z E_{i t}+\Sigma \beta_{4} R O A_{i t}+\Sigma \beta_{5} A G E_{i t}+\Sigma \beta_{6}$ $B-S I Z E_{i t}+\varepsilon_{i t}$ 
Model 3-CSR $R_{i t}=\beta_{0}+\Sigma \beta_{1} S H A N N O N_{i t}+\Sigma \beta_{2} L E V E R_{i t}+\Sigma \beta_{3} F-S I Z E_{i t}+\Sigma \beta_{4} R O A_{i t}+\Sigma \beta_{5} A G E_{i t}$ $+\Sigma \beta_{6} B-S I Z E_{i t}+\varepsilon_{i t}$

where,

CSR refers to CSR expenditure, our proxy for Sustainability Measure.

P- WOMAN represents the percentage of women directors on board.

LEVER refers to Leverage of firm.

F-SIZE refers to the size of the firm.

ROA refers to the Return on Assets.

AGE is the age of the firm.

B-SIZE refers to the size of the firm's board.

BLAU \& SHANON are the indices which are our proxy for gender diversity. $i$ refers to the various firms included in the sample of the time.

$\mathrm{t}$ is the time measured in years from 2014 to 2019.

\section{RESULTS AND ANALYSIS}

\section{Descriptive Statistics}

Table 2 clearly depicts that the mean average of the two indices are 0.26 and 0.19 , respectively. These low numbers point to the fact that the diversity in the firms' boards is quite less to have any impact on Corporate Social Responsibility. Not only this, but the average proportion of females on board is $17.4 \%$ only amongst the 210 firm year observations, which is again low. This points to the fact that there has been no true enhancement in gender diversity in these firms. The average assets are Rs.1590.86 crores and the return on assets is $5.388 \%$ which speaks of sound financial health of the firms on an average. The lower leverage ratio, which stand at an average of approximately 0.157 , are good as it depicts that less assets are financed by using the debt.

Table 2: Descriptive Statistics

\begin{tabular}{|c|c|c|c|c|c|c|c|c|c|}
\hline Measure & BLAU & SHANNON & P-WOMAN & $\begin{array}{l}\text { TOTAL } \\
\text { ASSETS }\end{array}$ & ROA & LEVER & AGE & CSR & B-Size \\
\hline MEAN & 0.261 & 0.195266 & 17.403 & 1590.856 & 5.388 & 0.157 & 49.94 & 98.80 & 12.22 \\
\hline MAXIMUM & 0.468 & 0.661563 & 37.5 & 9318.82 & 22.4 & 1.947 & 148 & 904 & 25 \\
\hline MINIMUM & 0.142 & 0.271189 & 7.6923 & 152.93 & -20.22 & -0.751 & 9 & $\mathbf{0}$ & 4 \\
\hline STD. DEV & 0.083 & 0.100128 & 7.004 & 1791.165 & 6.161 & 0.524 & 27.86 & 138.67 & 3.22 \\
\hline
\end{tabular}

\section{Source: Author's own calculations}

\section{Hausman Test}

We performed a Hausman test to test for Endogeneity in our models.

Table 3: Hausman Test 


\begin{tabular}{|l|l|l|l|}
\hline Test Summary & Chi-Sq statistic & Chi-Sq-d.f & p-value \\
\hline Cross section random & 21.858 & 8 & 0.000 \\
\hline
\end{tabular}

Source: Author's own calculations

The test clearly suggests the use of Fixed Effects Model to run our regression tests.

Table 4: Model Fitness Determination

\begin{tabular}{|l|l|l|l|}
\hline Models & R & R2 & Adjusted R2 \\
\hline 1 & .706 & .499 & .484 \\
\hline 2 & .707 & .500 & .485 \\
\hline 3 & .707 & .499 & .484 \\
\hline
\end{tabular}

Source: Author's own calculations

Table 4 shows the fitness of each of the model. As is clear from the table, all the three models are a fair fit with an adjusted R-squared of $48.4 \%$ approximately.

Table 5: Summary Results of Regression Models

\begin{tabular}{|l|l|l|l|l|l|l|l|l|}
\hline \multicolumn{2}{|l|}{ Model 1 } & \multicolumn{2}{l|}{ Model 2 } & Model 3 & p-value \\
\hline Variable & $\begin{array}{l}\text { t- } \\
\text { statistic }\end{array}$ & p-value & Variable & $\begin{array}{l}\text { - } \\
\text { statistic }\end{array}$ & p-value & Variable & $\begin{array}{l}\text { t- } \\
\text { statistic }\end{array}$ & -van \\
\hline P-woman & 0.022 & 0.982 & Blau & -0.394 & 0.694 & Shannon & -0.332 & 0.740 \\
\hline Leverage & -4.015 & $0.000^{*}$ & Leverage & -4.045 & $0.000^{*}$ & Leverage & -4.002 & $0.000^{*}$ \\
\hline Firm Size & 13.139 & $0.000^{*}$ & Firm Size & 13.161 & $0.000^{*}$ & Firm Size & 13.145 & $0.000^{*}$ \\
\hline ROA & 3.516 & $0.001^{*}$ & ROA & 3.549 & $0.000^{*}$ & ROA & 3.553 & $0.000^{*}$ \\
\hline Age & 2.470 & $0.014^{* *}$ & Age & 2.406 & $0.017^{* *}$ & Age & 2.430 & $0.016^{* *}$ \\
\hline B-Size & 0.001 & 0.999 & B-Size & -0.46 & 0.963 & B-Size & -0.040 & 0.968 \\
\hline
\end{tabular}

Source: Author's own calculations

*Significant at $1 \%$

** Significant at $\mathbf{5 \%}$

Table 5 summarizes the results of our regression models. Significance at $1 \%$ and $5 \%$ has been tested. Under Model 1, the percentage of women on board has a positive but insignificant impact on the CSR expenditure. This means that gender diversity or presence of women on board of companies does not have any impact on the sustainable or socially responsible behavior of firms as measured by CSR expenditure. The same is reiterated by our Model 2 and Model 3, where the Blau Index and Shannon Index, respectively, also have positive but insignificant impact on CSR expenditure.

As far as the control variable are concerned, majority of them show the expected signs and magnitude of impact under all the models. Leverage, that is the proportion of debt in the firm's total capital has a negative and significant impact on CSR.

Similarly, with the increase in firm size and return on assets, a firm has greater funds at its disposal for CSR initiatives. Hence, they have a positive and significant impact on CSR activities and expenses. As for age of firm, the longer the firm has been in business, the positive is the impact on corporate social expenditure. Lastly, the size of board, that is, the number of directors on board does not seem to have any significant impact on CSR expenditure in our 
study.

\section{CONCLUSION}

The results of our study suggest that gender diversity has a positive impact on CSR expenditure of the firm, although the impact is not significant. However, this also indicates that appointment of women on firms' board has not led to any negative effect on the social responsibility as well. The insignificant relationship points to the fact that such is a mere token exercise. Clearly, the ratio of women is less to influence CSR decisions. Also, gender discrimination and stereotyping challenge is one of the major reasons why women have not been able to make full contribution towards the corporate strategy \& leadership positions in their firms (Galbreath, 2011; Issa and Fang, 2019). According to De Cabo, Gimeno and Nieto (2012), there still exists prejudices and judgements towards the abilities of the women directors with respect to the handling of management positions. Moreover, if we diversify the board owing to the external pressures, such kind of diversity is value destroying and firm demeaning (Weisbach, 1998).

According to some of the previous literature (KONRAD, KRAMER and ERKUT, 2008; Torchia et al., 2010) it is said that the critical mass of women directors plays a significant role. These could have been some of the reasons due to which we could not see any significant impact of diversity on CSR activities. Thus, we may conclude that appointment of women on board is done by the companies to just fulfil the requirements of the Companies Act, 2013. In simple words, we can say that the stereotypes and prejudices with respect to the female directors, as well as the low level of diversity, have led to diversity acting as a bane than a boon for the CSR activities. In terms of the control variables, it is found that firm size has positive and significant effect on the CSR initiatives. It is more likely for larger firms to be exposed to the check and balances, and therefore they tend to be more focussed towards the stakeholders, leading to promoting better CSR activities and reputation of the firm (Valls Martínez, Cruz Rambaud and Parra Oller, 2019). Also since large sized firms are better equipped financially, they are able to spend more on CSR related activities (Boulouta, 2013; Sial et al., 2018; Francoeur et al., 2019). Firms use society's resources to a great extent and the more profitable the firm is, the more is the expectations from the firms with respect to the transparency and ethical activities (Báez et al., 2018). Thus, it has been found that firms with better profitability tend to have positive and significant impact on CSR (Dienes and Velte, 2016; Issa and Fang, 2019). Leverage of the firm has also turned out to be positively affecting the CSR based activities since it enhances the firm's capacity to undertake more such initiatives because of the financial stability and debts being covered by the assets of the firms. This is in conformation with prior studies (Issa and Fang, 2019; Pucheta-Martínez, Bel-Oms and Olcina-Sempere, 2019). Age of the firm has also shown significant and positive relationship with the CSR activities, since an older firm is more aware about its reputation and hence takes more careful view of the CSR related activities, as has been documented in the past literature as well (Francoeur et al., 2019).

Board size also has shown a positive but insignificant result. This may be because even after having larger boards, majority of them were male members, and their inclination towards the CSR activities would have been relatively less. Positive relation between board size and CSR has been found in several studies (Issa and Fang, 2019; Pucheta-Martínez, Bel-Oms and Olcina-Sempere, 2019).

\section{POLICY IMPLICATIONS, FUTURE SCOPE AND LIMITATIONS}

The study, apart from making valuable contributions to the literature, also provides some 
recommendations for the policymakers and firms. Firstly, policy makers and firms must consider the regulations in full spirit and not in mere letter form. Just following the law while maintaining the stereotypes and prejudices with respect to the abilities of women directors, is not going to add to the benefits that could have been derived at large because of diversity. Secondly, stricter laws with respect to appointment of independent women directors on boards can bring about a change in how gender diversity is perceived and implemented within firms. Mere appointment of female directors is acting as a hoax since the female directors are related to the promoters and do not bring any advantage on the table due to lack of transparency. Thirdly, the critical mass theory shall be considered while framing policies regarding the minimum female directors that should mandatorily be appointed on the board of certain categories of firms, so that a fair representation can allow women directors to voice their opinions in the boardroom.

As a limitation of this study, the sample includes 42 firms, which makes it less representative of the whole population. A larger sample may give better results. Moreover, in future studies, a larger time horizon and other proxy variables that are more representative of the CSR related elements such as disclosure index, can also be constructed for better and adequate results.

\section{REFERENCES}

Abdelzaher, A. and Abdelzaher, D. (2019). Women on Boards And Firm Performance In Egypt: Post The Arab Spring. The Journal of Developing Areas, 53(1), 225-241. doi: 10.1353/jda.2019.0013.

Abdullah, S. N., Ismail, K. N. I. K. and Nachum, L. (2016). Does having women on boards create value? the impact of societal perceptions and corporate governance in emerging markets. Strategic Management Journal, 37(3), 466-476. doi: 10.1002/smj.2352.

Adams, R. B. and Funk, P. (2012). Beyond the glass ceiling: Does gender matter?. Management Science, 58(2), 219-235. doi: 10.1287/mnsc.1110.1452.

Ahmad, N. B. J., Rashid, A., \& Gow, J. (2017). Board independence and corporate social responsibility (CSR) reporting in Malaysia. Australasian Accounting, Business and Finance Journal, 11(2), 61-85.doi:10.14453/aabfj.v11i2.5

Al Fadli, A., Sands, J., Jones, G., Beattie, C., \& Pensiero, D. (2019). Board gender diversity and CSR reporting: Evidence from Jordan. Australasian Accounting Business and Finance Journal, 13(3), 29-52.doi:10.14453/aabfj.v13i3.3

Alonso-Almeida, M. D. M., Perramon, J., \& Bagur-Femenias, L. (2017). Leadership styles and corporate social responsibility management: Analysis from a gender perspective. Business Ethics: A European Review, 26(2), 147-161.doi: 10.1111/beer.12139.

Báez, A. B., Báez-García, A. J., Flores-Muñoz, F., \& Gutiérrez-Barroso, J. (2018). Gender diversity, corporate governance and firm behavior: The challenge of emotional management. European Research on Management and Business Economics, 24(3), 121-129.doi: 10.1016/j.iedeen.2018.07.001.

Barnea, A., \& Rubin, A. (2010). Corporate social responsibility as a conflict between shareholders. Journal of Business Ethics, 97(1), 71-86.doi: 10.1007/s 10551-010- 
0496-z.

Bear, S., Rahman, N., \& Post, C. (2010). The impact of board diversity and gender composition on corporate social responsibility and firm reputation. Journal of Business Ethics, 97(2), 207-221. doi: 10.1007/s10551-010-0505-2.

Beattie, V., McInnes, B., \& Fearnley, S. (2004, September). A methodology for analysing and evaluating narratives in annual reports: a comprehensive descriptive profile and metrics for disclosure quality attributes. Accounting Forum, 28(3), 205-236). doi: 10.1016/j.accfor.2004.07.001.

Boulouta, I. (2013). Hidden connections: The link between board gender diversity and corporate social performance. Journal of Business Ethics, 113(2), 185-197.doi: 10.1007/s10551-012-1293-7.

Byron, K., \& Post, C. (2016). Women on boards of directors and corporate social performance: A meta-analysis. Corporate Governance: An International Review, 24(4), 428-442.doi: 10.1111/corg.12165.

De Cabo, R. M., Gimeno, R., \& Nieto, M. J. (2012). Gender diversity on European banks' boards of directors. Journal of Business Ethics, 109(2), 145-162.doi: 10.1007/s10551-011-1112-6.

Campbell, J. L. (2007). Why would corporations behave in socially responsible ways? An institutional theory of corporate social responsibility. Academy of Management Review, 32(3), 946-967.doi: 10.5465/AMR.2007.25275684.

Campbell, K., \& Mínguez-Vera, A. (2008). Gender diversity in the boardroom and firm financial performance. Journal of Business Ethics, 83(3), 435-451.doi: 10.1007/s10551-007-9630-y.

Chams, N., \& García-Blandón, J. (2019). Sustainable or not sustainable? The role of the board of directors. Journal of Cleaner Production, 226, 1067-1081.doi: 10.1016/j.jclepro.2019.04.118.

Chancharat, S., \& Chancharat, N. (2019). Board structure, ownership structure, and performance of Thai listed companies. Australasian Accounting, Business and Finance Journal, 13(3), 53-70.doi: 10.14453/aabfj.v13i3.4.

Charumathi, B., \& Rahman, H. (2019). Do women on boards influence climate change disclosures to CDP?-evidence from large Indian companies. Australasian Accounting, Business and Finance Journal, 13(2), 5-31. doi: 10.14453/aabfj.v13i2.2.

Daily, C.M. and Dalton, D.R. (2003). Women in the boardroom: a business imperative. Journal of Business Strategy, 24(5). https://doi.org/10.1108/jbs.2003.28824eaf.002.

Dienes, D., \& Velte, P. (2016). The impact of supervisory board composition on CSR reporting. Evidence from the German two-tier system. Sustainability, 8(1), 63., doi: $10.3390 /$ su8010063.

Doherty, E. G. and Eagly, A. H. (1989). Sex Differences in Social Behavior: A Social-Role Interpretation. Contemporary Sociology.18(3), 343. doi: 10.2307/2073813. 
Donaldson, T., \& Preston, L. E. (1995). The stakeholder theory of the corporation: Concepts, evidence, and implications. Academy of Management Review, 20(1), 65-91.doi: 10.5465/amr.1995.9503271992.

Eagly, A. H., Johannesen-Schmidt, M. C., \& Van Engen, M. L. (2003). Transformational, transactional, and laissez-faire leadership styles: a meta-analysis comparing women and men. Psychological Bulletin, 129(4), 569.doi: 10.1037/0033-2909.129.4.569.

Eagly, A. H., \& Karau, S. J. (1991). Gender and the emergence of leaders: A meta-analysis. Journal of Personality and Social Psychology, 60(5), 685.doi: 10.1037/00223514.60.5.685.

Eagly, A. H., \& Wood, W. (1991). Explaining sex differences in social behavior: A metaanalytic perspective. Personality and Social Psychology Bulletin, 17(3), 306-315.doi: 10.1177/0146167291173011.

Esa, E., \& Ghazali, N. A. M. (2012). Corporate social responsibility and corporate governance in Malaysian government-linked companies. Corporate Governance,13(3),292-305. doi: 10.1108/14720701211234564.

Fondas, N. (2000). Women on boards of directors: gender bias or power threat?. Women on Corporate Boards of Directors (pp. 171-177). doi: 10.1007/978-90-481-3401-4_12.

Francoeur, C., Labelle, R., Balti, S., \& Bouzaidi, S. E. (2019). To what extent do gender diverse boards enhance corporate social performance?. Journal of Business Ethics, 155(2), 343-357. doi: 10.1007/s10551-017-3529-z.

Galbreath, J. (2011). Are there gender-related influences on corporate sustainability? A study of women on boards of directors. Journal of Management \& Organization, 17(1), 1738.doi: 10.1017/s1833367200001693.

Gilligan, C. (1977). In a different voice: Women's conceptions of self and of morality. Harvard Educational Review, 47(4), 481-517. doi: 10.17763/haer.47.4.g6167429416hg510.

Giraldez-Puig, P., \& Berenguer, E. (2018). Family female executives and firm financial performance. Sustainability, 10(11), 4163. doi: 10.3390/su10114163.

Haldar, A. et al. (2018) 'Corporate Performance: Does Board Independence Matter? - Indian evidence', International Journal of Organizational Analysis. 26(1),185-200. doi: 10.1108/IJOA-12-2017-1296.

Haldar, A., Shah, R., \& Nageswara Rao, S.V.D.(2015). Gender diversity in large listed Indian companies. Corporate Ownership \& Control, 12(3-5), 573-580. https://doi.org/10.22495/cocv12i3c5p8

Haniffa, R. M., \& Cooke, T. E. (2005). The impact of culture and governance on corporate social reporting. Journal of Accounting and Public Policy, 24(5), 391-430. doi: 10.1016/j.jaccpubpol.2005.06.001. 
Harjoto, M., Laksmana, I., \& Lee, R. (2015). Board diversity and corporate social responsibility. Journal of Business Ethics, 132(4), 641-660. doi: 10.1007/s10551014-2343-0.

Hashim, F., Ahmed, E. R., \& Huey, Y. M. (2019). Board Diversity and Earning Quality: Examining the Role of Internal Audit as a Moderator. Australasian Accounting, Business and Finance Journal, 13(4), 73-91. doi: 10.14453/aabfj.v13i4.6.

Hausman, J. A., \& Taylor, W. E. (1981). Panel data and unobservable individual effects. Econometrica: Journal of the Econometric Society, 1377-1398. doi: $10.2307 / 1911406$.

Herrera-Cano, C. and Gonzalez-Perez, M.A. (2019). Representation of Women on Corporate Boards of Directors and Firm Financial Performance. Diversity within Diversity Management (Advanced Series in Management, Vol. 22), Emerald Publishing Limited, Bingley, 37-60. https://doi.org/10.1108/S1877-636120190000022003

Issa, A. and Fang, H. X. (2019). The impact of board gender diversity on corporate social responsibility in the Arab Gulf states. Gender in Management, 34(7), pp. 577-605. doi: 10.1108/GM-07-2018-0087.

Jamali, D., \& Neville, B. (2011). Convergence versus divergence of CSR in developing countries: An embedded multi-layered institutional lens. Journal of Business Ethics, 102(4), 599-621.doi: 10.1007/s10551-011-0830-0.

Jamali, D. R., El Dirani, A. M., \& Harwood, I. A. (2015). Exploring human resource management roles in corporate social responsibility: The CSR-HRM co-creation model. Business Ethics: A European Review, 24(2), 125-143. doi: 10.1111/beer.12085.

Jo, H., \& Harjoto, M. A. (2011). Corporate governance and firm value: The impact of corporate social responsibility. Journal of Business Ethics, 103(3), 351-383.doi: 10.1007/s10551-011-0869-y.

Karim, S., Manab, N. A., \& Ismail, R. B. (2019). The dynamic impact of board composition on CSR practices and their mutual effect on organizational returns. Journal of Asia Business Studies.doi: 10.1108/JABS-07-2019-0214.

Kesner, I. F. (1988). Directors' characteristics and committee membership: An investigation of type, occupation, tenure, and gender. Academy of Management Journal, 31(1), 6684.doi: $10.5465 / 256498$.

Konrad, A. M., Kramer, V., \& Erkut, S. (2008). The impact of three or more women on corporate boards. Organizational Dynamics, 37(2), 145-164. doi: 10.1016/j.orgdyn.2008.02.005.

Landry, E. E., Bernardi, R. A., \& Bosco, S. M. (2016). Recognition for sustained corporate social responsibility: Female directors make a difference. Corporate Social Responsibility and Environmental Management, 23(1), 27-36.doi: 10.1002/csr.1358.

Liao, P. C., Shih, Y. N., Wu, C. L., Zhang, X. L., \& Wang, Y. (2018). Does corporate social 
performance pay back quickly? A longitudinal content analysis on international contractors. Journal of Cleaner Production, 170, 1328-1337.doi:

10.1016/j.jclepro.2017.09.230.

Lückerath-Rovers, M. (2013). Women on boards and firm performance. Journal of Management \& Governance, 17(2), 491-509.. doi: 10.1007/s10997-011-9186-1.

Major, B., \& Forcey, B. (1985). Social comparisons and pay evaluations: Preferences for same-sex and same-job wage comparisons. Journal of Experimental Social Psychology, 21(4), 393-405.doi: 10.1016/0022-1031(85)90038-1.

McWilliams, A., \& Siegel, D. (2001). Corporate social responsibility: A theory of the firm perspective. Academy of Management Review, 26(1), 117-127.doi: 10.2307/259398.

Mínguez-Vera, A. and López-Martínez, R., 2010. Female directors and SMES: An empirical analysis. Journal of Global Strategic Management, 8(2), pp.34-46. doi: 10.20460/JGSM.2010415823

Moreno-Gómez, J., Lafuente, E., \& Vaillant, Y. (2018). Gender diversity in the board, women's leadership and business performance. Gender in Management: An International Journal, 33(2), 104-122. doi: 10.1108/GM-05-2017-0058.

Muttakin, M. B., Khan, A., \& Mihret, D. G. (2018). The effect of board capital and CEO power on corporate social responsibility disclosures. Journal of Business Ethics, 150(1), 41-56.doi: 10.1007/s10551-016-3105-y.

Nadeem, M., Zaman, R. and Saleem, I. (2017) 'Boardroom gender diversity and corporate sustainability practices: Evidence from Australian Securities Exchange listed firms', Journal of Cleaner Production. Elsevier B.V., 149, pp. 874-885. doi: 10.1016/j.jclepro.2017.02.141.

Nielsen, S. and Huse, M. (2010a) 'The contribution of women on boards of directors: Going beyond the surface', Corporate Governance: An International Review. 18(2),136148. doi: 10.1111/j.1467-8683.2010.00784.x.

Nielsen, S. and Huse, M. (2010b) 'Women directors' contribution to board decision-making and strategic involvement: The role of equality perception', European Management Review. 7(1),16-29. doi: 10.1057/emr.2009.27.

Post, C., Rahman, N., \& Rubow, E. (2011). Green governance: Boards of directors’ composition and environmental corporate social responsibility. Business \& Society, 50(1), 189-223.doi: 10.1177/0007650310394642.

Prasad, M., Mishra, T. and Bapat, V. (2019) 'Corporate social responsibility and environmental sustainability: Evidence from India using energy intensity as an indicator of environmental sustainability', IIMB Management Review. Elsevier Ltd, 31(4), 374-384. doi: 10.1016/j.iimb.2019.07.014.

Prasad, M., Mishra, T., \& Kalro, A. D. (2017). Environmental disclosure by Indian companies: an empirical study. Environment, Development and Sustainability, 19(5), 1999-2022.doi: 10.1007/s10668-016-9840-5. 
Pucheta-Martínez, M. C., Bel-Oms, I., \& Olcina-Sempere, G. (2019). Commitment of independent and institutional women directors to corporate social responsibility reporting. Business Ethics: A European Review, 28(3), 290-304.doi: 10.1111/beer.12218.

Pucheta-Martínez, M. C., \& Gallego-Álvarez, I. (2020). Corporate environmental disclosure practices in different national contexts: The influence of cultural dimensions. Organization \& Environment, 33(4), 597-623.doi: 10.1177/1086026619860263.

Rahman, H.-U.-, Ibrahim, M. Y. and Ahmad, A. C. (2017) 'Corporate governance reforms and shareholders' confidence in emerging markets', World Journal of Science, Technology and Sustainable Development. 14(1),60-74. doi: 10.1108/wjstsd-092016-0054.

Rahman, H. U., Ibrahim, M. Y., \& Ahmad, A. C. (2017). Physical characteristics of the chief executive officer and firm accounting and market-based performance. Asian Journal of Accounting and Governance, 8, 27-37.doi: 10.17576/ajag-2017-08-03.

Rao, K., \& Tilt, C. (2016). Board composition and corporate social responsibility: The role of diversity, gender, strategy and decision making. Journal of Business Ethics, 138(2), 327-347.doi: 10.1007/s10551-015-2613-5.

Reguera-Alvarado, N., De Fuentes, P., \& Laffarga, J. (2017). Does board gender diversity influence financial performance? Evidence from Spain. Journal of Business Ethics, 141(2), 337-350.doi: 10.1007/s 10551-015-2735-9.

Robinson, G., \& Dechant, K. (1997). Building a business case for diversity. Academy of Management Perspectives, 11(3), 21-31. doi: 10.5465/ame.1997.9709231661.

Sanan, N. K. (2016). Board gender diversity, financial and social performance of Indian firms. Vision, 20(4), 361-367.doi: 10.1177/0972262916673006.

Sial, M. S., Zheng, C., Cherian, J., Gulzar, M. A., Thu, P. A., Khan, T., \& Khuong, N. V. (2018). Does corporate social responsibility mediate the relation between boardroom gender diversity and firm performance of Chinese listed companies?. Sustainability, 10(10), 3591.doi: 10.3390/su10103591.

Singh, A. K., Singhania, S. and Sardana, V. (2019) 'Do Women on Boards affect Firm's Financial Performance? Evidence from Indian IPO Firms', Australasian Accounting, Business and Finance Journal, 13(2), pp. 53-68. doi: 10.14453/aabfj.v13i2.4.

Smith, N., Smith, V. and Verner, M. (2006) 'Do women in top management affect firm performance? A panel study of 2,500 Danish firms', International Journal of Productivity and Performance Management. 55(7), 569-593. doi: 10.1108/17410400610702160.

Torchia, M. et al. (2010) 'Critical mass theory and women directors' contribution to board strategic tasks', Corporate Board: Role, Duties and Composition.6(3),42-51. doi: 10.22495/cbv6i3art4.

Torchia, M., Calabrò, A., \& Huse, M. (2011). Women directors on corporate boards: From 
tokenism to critical mass. Journal of Business Ethics, 102(2), 299-317.doi: 10.1007/s10551-011-0815-Z.

Tourigny, L., Han, J. and Baba, V.V. (2017). Does gender matter? A study of trust and its outcomes in the manufacturing sector in mainland China. Gender in Management, 32(8), 554-577. https://doi.org/10.1108/GM-05-2016-0106

Valls Martínez, M. del C., Cruz Rambaud, S. and Parra Oller, I. M. (2019) 'Gender policies on board of directors and sustainable development', Corporate Social Responsibility and Environmental Management, 26(6), pp. 1539-1553. doi: 10.1002/csr.1825.

Van Knippenberg, D., De Dreu, C. K., \& Homan, A. C. (2004). Work group diversity and group performance: an integrative model and research agenda. Journal of Applied Psychology, 89(6), 1008.doi: 10.1037/0021-9010.89.6.1008.

Verma, A., \& Kumar, C. V. (2014). An analysis of CSR expenditure by Indian companies. Indian Journal of Corporate Governance, 7(2), 82-94.doi: 10.1177/0974686220140201.

Waddock, S. A., \& Graves, S. B. (1997). The corporate social performance-financial performance link. Strategic Management Journal, 18(4), 303-319. doi: 10.1002/(SICI)1097-0266(199704)18:4<303::AID-SMJ869>3.0.CO;2-G.

Wang, J., \& Coffey, B. S. (1992). Board composition and corporate philanthropy. Journal of Business Ethics, 11(10), 771-778. doi: 10.1007/BF00872309.

Hermalin, B. E., \& Weisbach, M. S. (1998). Endogenously Chosen Boards of Directors and Their Monitoring of the CEO. The American Economic Review, 88(1), 96-118. doi: 10.1017/CBO9781107415324.004.

Zahid, M., Rahman, H, Ali, W., Khan, M., Alharthi, M., Qureshi, M., \& Jan, A. (2020) 'Boardroom gender diversity: Implications for corporate sustainability disclosures in Malaysia', Journal of Cleaner Production. 244. doi: 10.1016/j.jclepro.2019.118683.

Zaichkowsky, J. L. (2014). Women in the board room: One can make a difference. International Journal of Business Governance and Ethics, 9(1), 91-113. doi: 10.1504/IJBGE.2014.062774. 